\title{
Emergence on the continental shelf: differences among species and between microhabitats
}

\author{
Linda Sedlacek, David Thistle* \\ Department of Oceanography, Florida State University, Tallahassee, Florida 32306-4320, USA
}

\begin{abstract}
Emergence, the phenomenon in which a normally benthic individual leaves the seabed, enters the water column, and then returns to the seabed, is widespread among taxa and among environments and can be important to such issues as benthopelagic coupling and benthic-community organization. Emergence is far from completely understood, particularly in shelf environments. We studied a sandy site on the north Florida shelf $\left(30^{\circ} 22.65^{\prime} \mathrm{N}, 86^{\circ} 38.69^{\prime} \mathrm{W}, 20 \mathrm{~m}\right.$ depth $)$ and focused on harpacticoid copepods, known to be important emergers. To test for differences among shelf species in the proportion of the population that emerged daily, we used an approach that allowed us to perceive proportions as small as $\sim 1 \%$ and found that species ranged from $\sim 1$ to $\sim 80 \%$ in percentage emergence. Of 3 adaptations proposed in the literature to explain differences among species in emergence, we found that one, the average area of the cephalosome in dorsal view (a correlate of swimming ability), explained a significant and nontrivial amount of the variability. In addition, microhabitats (sediment ripple crests and troughs) significantly affected emergence in 3 species. Within microhabitats, emergence behavior did not appear to be a response to intraspecific crowding. Our results suggest that the number of harpacticoids that emerge from a locality can be quite variable and depends on both the type of microhabitat and the identities of the species present.
\end{abstract}

KEY WORDS: Emergence $\cdot$ Harpacticoid copepods $\cdot$ Continental shelf

\section{INTRODUCTION}

Some groups traditionally thought to be benthic as adults, such as polychaetes, ostracods, and harpacticoid copepods, include species that emerge (Alldredge \& King 1980). That is, every $24 \mathrm{~h}$, a portion of the population swims out of the sediment, spends time in the water column (typically during the night), and then returns to the sediment. Emergence occurs worldwide in littoral (Grant 1981, Hicks 1986, Buffan-Dubau \& Castel 1996) and sublittoral (Jacoby \& Greenwood 1989, Thistle 2003) environments. Where it occurs, large numbers of individuals can move from the seabed to the water column and back daily (Armonies 1988), making it potentially important to such issues as benthopelagic coupling (Marcus \& Boero 1998), dispersal (Palmer et al. 1996), and benthic community organization (Commito \& Tita 2002, Thistle 2003).

Harpacticoid copepods emerge in large numbers from the continental shelf (Thistle 2003), but the de- gree to which species differ in the proportions of their populations that emerge is not known, so formulation of hypotheses about the causes of emergence in shelf species is difficult. In the work reported here, we found that up to $\sim 80 \%$ of the populations of some species emerged daily, but for other species, only $\sim 1 \%$ emerged.

The causes of such differences between species are not known for harpacticoids. Because morphological differences among species can sometimes suggest reasons for ecological differences (Remane 1952), we investigated characters proposed by Bell et al. (1987) for their ability to predict the proportion of a species' population that emerged.

Conditions in sediments vary in ways that can be important to harpacticoids. For example, low density, organic particles and smaller mineral particles are winnowed out as sediment ripple crests form but are deposited in troughs (Reimers et al. 2004). The bacteria on small organic and small mineral particles are 
sources of food for harpacticoids, and the relative abundances of different size classes of mineral particles influence the ability of harpacticoids to move through the sediment (Wieser 1959, Gray 1968, Ravenel \& Thistle 1981, Hicks \& Coull 1983), so crests and troughs should offer both different food supplies and different physical environments. Also, in permeable sediments such as those at our site, the horizontal flow field can interact with bed forms to create localized pressure differences (Huettel \& Gust 1992). In troughs, near-bottom water, which contains food particles and is oxygen rich, is pumped in, and near the apex of crests, pore water from centimeters deep in the bed, which tends to be low in oxygen and can be sulfide rich, is pumped out (Huettel et al. 1996, Ziebis et al. 1996, Huettel \& Webster 2001, Precht \& Huettel 2003). These differences can affect harpacticoids, either directly (Vopel et al. 1998) or indirectly through effects on their microbial food. Because differences in local environmental quality could influence the benefit to an individual of emerging or remaining in the sediment, we asked whether species' emergence in crests and troughs of sediment ripples differed.

In seagrass meadows, species' emergence has been shown to vary both positively and negatively with the degree of intraspecific crowding (Service \& Bell 1987). We asked whether such dependencies occurred in crests or in troughs.

\section{MATERIALS AND METHODS}

Study area. We studied a microtidal site at $20 \mathrm{~m}$ depth off Fort Walton Beach, Florida, USA $\left(30^{\circ} 22.65^{\prime} \mathrm{N}\right.$, $86^{\circ} 38.69^{\prime} \mathrm{W}$ ), from 3 to 8 November 1999 . The seabed was a medium sand (median grain size of $415 \mu \mathrm{m}$; Richardson et al. 2001), with ripple crests $\sim 2 \mathrm{~cm}$ tall and $\sim 10 \mathrm{~cm}$ wide separated by troughs 40 to $60 \mathrm{~cm}$ wide. The sediment surface of troughs was essentially flat. Water temperature varied between 21 and $23^{\circ} \mathrm{C}$, and salinity between 35.1 and 35.3 (Richardson et al. 2001).

Sampling. We collected emergent harpacticoids with inverted-funnel traps (see, for example, Alldredge \& King 1977, Hicks 1986, Bell et al. 1988, Walters 1988, Buffan-Dubau \& Castel 1996) of 2 types-base traps (the data from which were used in the present analysis) and leg traps (Fleeger et al. 1984, the data from which were used to check for bias in the base-trap data as described in the following section). Both were made of clear plastic that minimized light attenuation, which might alter the behavior of emergent organisms (Alldredge \& King 1980). Base traps (Fig. 1) consisted of 2 parts, a base and a collecting chamber. The base was inserted into the seabed to the level of its stabilizing ring, and the collecting chamber was then attached.
The cylindrical collecting chamber contained a clear, inverted funnel with sides that sloped at $60^{\circ}$ and openings $1.5 \mathrm{~cm}$ in diameter at the top and $10 \mathrm{~cm}$ in diameter at the bottom. The base was $10.2 \mathrm{~cm}$ in inner diameter and was pierced by 2 rows of eighteen $1.1 \mathrm{~cm}$ diameter ports covered with $63 \mu \mathrm{m}$ mesh. When the base was in place, the centers of the lower ports were $2.7 \mathrm{~cm}$ below the sediment surface, and those of the upper were $1.6 \mathrm{~cm}$ above it. The mesh-covered ports allowed some water exchange, but the water in a base trap was essentially still. The base held the funnel mouth $4.5 \mathrm{~cm}$ above the seabed. Leg traps had no bases. Their collecting chambers were identical to those used in the base traps and were held $4.5 \mathrm{~cm}$ above the seabed on 3 vertical legs mounted such that each was $26 \mathrm{~cm}$ from the side of the trap. Therefore, to be caught in a trap of either type, an animal would have to reach $15 \mathrm{~cm}$ above the seabed, a distance comparable to that for other traps that have been used (Hicks 1986, Service \& Bell 1987, Bell et al. 1988, Walters 1988).

Before trap deployment, seawater from $1 \mathrm{~m}$ above bottom was collected with a 51 Niskin bottle, passed through a $30 \mu \mathrm{m}$ sieve, and used to fill the collecting chambers. The funnel spout was closed temporarily with a stopper that prevented water exchange during transport. SCUBA divers placed traps at randomly chosen locations in the 1.5 by $60 \mathrm{~m}$ study area with the restriction that traps be located at least $2.7 \mathrm{~m} \mathrm{(10} \mathrm{diam-}$ eters) apart to reduce the possibility of hydrodynamic interference.

We placed 4 traps each day: a base trap on a crest, a base trap in a trough, a leg trap on a crest, and a leg trap in a trough. For base traps, divers inserted the

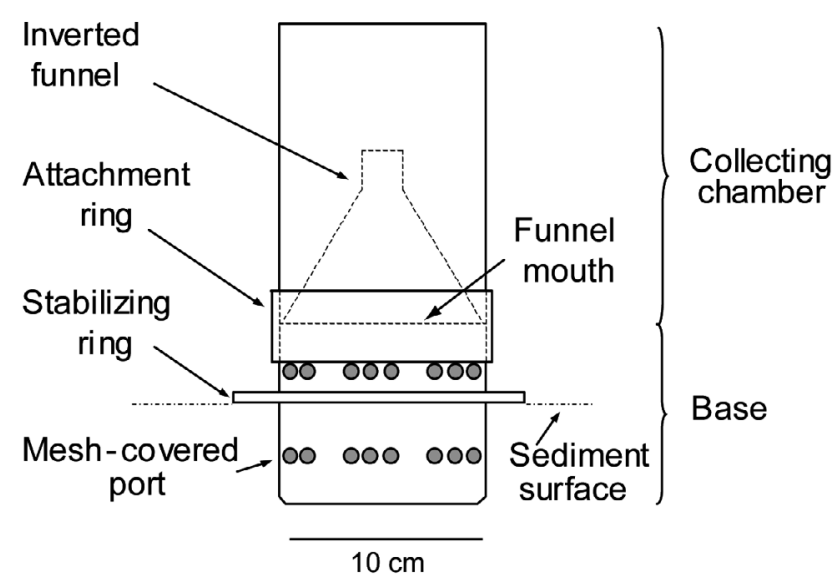

Fig. 1. Side view of a base trap, showing its components. Three stainless-steel stabilizing rods $(0.9 \mathrm{~cm}$ diameter, $20 \mathrm{~cm}$ long) are omitted; they were inserted horizontally just above the stabilizing ring and equidistant around the base 
base into the sediment and allowed $60 \mathrm{~s}$ for any suspended materials to resettle before removing the stopper from the collecting chamber and attaching the chamber to the base. For leg traps, the collecting chamber was attached to its legs, placed in position, and then unstoppered.

After approximately $24 \mathrm{~h}$, the traps were retrieved. For leg traps, a stopper was placed in the funnel spout of the collecting chamber, and the trap was removed. Because removal of the base trap, as a unit, from the seabed would suspend material inside the trap and risk contaminating the sample, we disconnected the collecting chamber from the base and stoppered the funnel spout.

We were unable to process all the individuals remaining in the sediment enclosed by the base, so we took a subsample, a $15.5 \mathrm{~cm}^{2}$ core, from the center of the base before it was removed from the sediment. To adjust for the unequal areas of sediment enclosed by base traps and collected in cores, we multiplied the number of adults of a species found in each core sample by 5.22 . The accuracy of our estimates of the proportion of a species' population that emerged depended on the extent to which the variability within the base was well sampled by our core. That we were able to perceive subtle patterns in emergence (see 'Results') suggests that our approach was adequate for many species. On deck, cores were sliced at $0.2 \mathrm{~cm}$ intervals to $1 \mathrm{~cm}$ depth with a precision extruder (Fuller \& Butman 1988). Two of the base traps from troughs were disturbed, and samples from them were not analyzed.

All samples were preserved in a sodium-boratebuffered solution of seawater and formaldehyde (9:1, $\mathrm{v}: \mathrm{v})$. Harpacticoid copepods were removed under a dissecting microscope after rose bengal staining. Adults were identified to working species with the aid of a compound microscope. We could not identify juveniles reliably because the fauna contained several groups of closely related species, and the characters needed to separate the species in these groups were not discernable until the adult molt. We used the taxonomic keys of Wells (1976) and Huys et al. (1996) and the primary literature to identify the species, but some were new to science. All analyses were done on adults.

Recognizing emergent species. To recognize species that emerged, we analyzed data from crests and troughs separately because environmental differences between them might change species' behavior. Species found only once (i.e. at 1 sampling location at 1 time) were omitted because their emergence could not be analyzed statistically. Species found only in the sediment were excluded because they were irrelevant to our questions.
Not all the remaining individuals found in base traps necessarily emerged. For example, despite the care taken by divers, the sediment might have been disturbed when the traps were deployed, and some individuals could have been inadvertently trapped. To avoid confusing those individuals with emergent individuals, we calculated the proportion of each species' population that emerged (the number of adults of a species caught by a base trap divided by the sum of that number and the number of adults of that species estimated to be in the sediment enclosed by the base trap). We then used randomization methods to calculate 2-tailed, $95 \%$ confidence intervals around the average proportion that emerged for each species using the PROFITS program (5000 repetitions) in Resampling Stats $\odot$ (Bruce 1991). The species whose confidence intervals included zero were excluded from further analyses.

Of the species whose confidence intervals did not include zero, some were found only in base traps and not in leg traps (i.e. they emerged only into still water) and therefore may not emerge into natural flows (Palmer 1988, Thistle 2003); these species were not considered further. Species found in both leg and base traps (i.e. those that emerged under both artificial and natural conditions) we considered to be emergers.

To test for differences in emergence between species, we compared the confidence intervals for all possible pairs of species separately for the crest data and for the trough data. (Note that in this and subsequent analyses, we used the base-trap data only because of uncertainties about how leg traps performed as quantitative collectors; see, for example, Robichaux et al. 1981). If 2 species' confidence intervals did not overlap, they were considered to be significantly different, i.e. no correction was made for multiple testing. All tests were 2 -tailed at the $5 \%$ significance level.

Emergence and morphological characters. In their study, Bell et al. (1987) used 3 characters measured on adult females: the ratio of the length of the first segment of the endopod of the first pereiopod to the length of segments 2 and 3 combined, the area of the cephalosome in dorsal view, and the length of the first antenna. We used their procedures to measure these characters on 5 adult females selected at random to obtain average values for each character for each of 12 species (see Tables 1 to 4 for species' identities). For each character, we used least-squares regression to test its ability to predict the proportion of a species' population that emerged from either crests or troughs, whichever was greater (because we were interested in the potential for a species to emerge). To assess the fit of our data to the assumptions of parametric regression, we inspected residual and normal probability plots.

Microhabitat differences. To test for a difference between crests and troughs in the proportion of a species' 
population that emerged, we compared the confidence intervals for crests and troughs for each species.

Intraspecific crowding. For each species that emerged from troughs (for a list, see Table 1), we plotted the proportion of its population that emerged against its density (i.e. the number of individuals caught in the trap plus the number estimated to be in the sediment enclosed by the trap) in each sample from troughs. We then fitted a linear, least-squares trend line. We repeated this procedure for the species that emerged from crests (for a list, see Table 2).

\section{RESULTS}

\section{Differences in emergence between species}

Of the 38 species we could analyze, 8 emerged from both crests and troughs, and a further 4 emerged from either crests or troughs but not both (Tables $1 \& 2$ ). The
$95 \%$ confidence intervals of many species did not overlap (Fig. 2), indicating that they differed significantly on a single-test basis (Tables 3 \& 4).

\section{Emergence and morphological characters}

Of Bell et al.'s (1987) 3 indices, only the regression of the proportion emerged on the area of the adult female cephalosome in dorsal view was significant $(p<0.002$, Fig. 3). The latter explained $60.7 \%$ of the variability (adjusted $\mathrm{R}^{2}$ ) of the former.

\section{Emergence and microhabitats}

For 3 (Halectinosoma sp. 1, Longipedia americana, and Robertsonia glomerata) of the 12 emergent species we examined individually, emergence was significantly greater from crests than from troughs (Fig. 2).

Table 1. For the species that emerged from troughs, the abundance in traps (Trap), the estimated abundance in the sediment (Sed), and the percentage emergence (\%) for each day of the experiment together with the mean percent emergence, showing the dramatic differences among species in the proportion of the population that emerged

\begin{tabular}{|c|c|c|c|c|c|c|c|c|c|c|c|c|c|}
\hline \multirow[t]{2}{*}{ Species } & \multicolumn{3}{|c|}{ Day 2} & \multicolumn{3}{|c|}{ Day 3} & \multicolumn{3}{|c|}{ Day 4} & \multicolumn{3}{|c|}{ Day 6} & \multirow[t]{2}{*}{ Mean } \\
\hline & Trap & Sed & $\%$ & Trap & Sed & $\%$ & Trap & Sed & $\%$ & Trap & Sed & $\%$ & \\
\hline Robertgurneya sp. & 1 & 412 & 0.2 & 7 & 527 & 1.3 & 0 & 491 & 0.0 & 8 & 632 & 1.3 & 0.7 \\
\hline Amphiascus minutus & 3 & 287 & 1.0 & 9 & 256 & 3.4 & 9 & 172 & 5.0 & 15 & 329 & 4.4 & 3.4 \\
\hline Amphiascus varians & 3 & 78 & 3.7 & 10 & 146 & 6.4 & 14 & 110 & 11.3 & 5 & 172 & 2.8 & 6.1 \\
\hline Ameiropsis mixtra & 6 & 26 & 18.8 & 7 & 78 & 8.2 & 15 & 47 & 24.2 & 6 & 172 & 3.4 & 13.6 \\
\hline Ameira sp. & 10 & 99 & 9.2 & 16 & 57 & 21.9 & 9 & 188 & 4.6 & 18 & 63 & 22.2 & 14.5 \\
\hline Ectinosoma sp. & 19 & 73 & 20.7 & 10 & 57 & 14.9 & 44 & 73 & 37.6 & 11 & 16 & 40.7 & 28.5 \\
\hline Longipedia americana & 56 & 99 & 36.1 & 43 & 141 & 23.4 & 131 & 224 & 36.9 & 157 & 183 & 46.2 & 35.6 \\
\hline Pseudobradya cf. exilis & 3 & 26 & 10.3 & 0 & 0 & - & 2 & 37 & 5.1 & 1 & 0 & 100 & 38.5 \\
\hline cf. Paradactylopodia & 11 & 21 & 34.4 & 8 & 0 & 100 & 4 & 5 & 44.4 & 11 & 0 & 100 & 69.7 \\
\hline
\end{tabular}

Table 2. For the species that emerged from crests, the abundance in traps (Trap), the estimated abundance in the sediment (Sed), and the percentage emergence $(\%)$ for each day of the experiment together with the mean percent emergence, showing the dramatic differences among species in the proportion of the population that emerged

\begin{tabular}{|c|c|c|c|c|c|c|c|c|c|c|c|c|c|c|c|c|c|c|c|}
\hline \multirow[t]{2}{*}{ Species } & \multicolumn{3}{|c|}{ Day 1} & \multicolumn{3}{|c|}{ Day 2} & \multicolumn{3}{|c|}{ Day 3} & \multicolumn{3}{|c|}{ Day 4} & \multicolumn{3}{|c|}{ Day 5} & \multicolumn{3}{|c|}{ Day 6} & \multirow[t]{2}{*}{ Mean } \\
\hline & Trap & Sed & $\%$ & Trap & Sed & $\%$ & Trap & Sed & $\%$ & Trap & Sed & $\%$ & Trap & Sed & $\%$ & Trap & $p$ Sed & $\%$ & \\
\hline Robertgurneya sp. & 2 & 115 & 1.7 & 2 & 120 & 1.6 & 1 & 459 & 0.2 & 1 & 157 & 0.6 & 1 & 313 & 0.3 & 5 & 391 & 1.3 & 1.0 \\
\hline Amphiascus minutus & 10 & 94 & 9.6 & 5 & 104 & 4.6 & 3 & 344 & 0.9 & 6 & 167 & 3.5 & 14 & 78 & 15.2 & 17 & 313 & 5.2 & 6.5 \\
\hline Amphiascus varians & 3 & 26 & 10.3 & 3 & 21 & 12.5 & 1 & 42 & 2.3 & 7 & 94 & 6.9 & 2 & 63 & 3.1 & 5 & 89 & 5.3 & 6.7 \\
\hline Ameiropsis mixtra & 1 & 26 & 3.7 & 0 & 21 & 0.0 & 3 & 183 & 1.6 & 8 & 68 & 10.5 & 19 & 183 & 9.4 & 9 & 37 & 19.6 & 7.5 \\
\hline Ectinosoma sp. & 8 & 10 & 44.4 & 0 & 21 & 0.0 & 13 & 37 & 26.0 & 12 & 5 & 70.6 & 6 & 21 & 22.2 & 9 & 21 & 30.0 & 32.2 \\
\hline cf. Paradactylopodia & 4 & 10 & 28.6 & 2 & 5 & 28.6 & 2 & 5 & 28.6 & 3 & 10 & 23.1 & 4 & 5 & 44.4 & 7 & 5 & 58.3 & 35.3 \\
\hline Longipedia americana & 97 & 110 & 46.9 & 76 & 31 & 71.0 & 46 & 21 & 68.7 & 49 & 193 & 20.2 & 64 & 21 & 75.3 & 63 & 5 & 92.6 & 62.5 \\
\hline Halectinosoma sp. 1 & 1 & 0 & 100 & 0 & 0 & - & 2 & 5 & 28.6 & 0 & 0 & - & 2 & 0 & 100 & 1 & 0 & 100 & 82.1 \\
\hline
\end{tabular}


Our results are unlikely to be caused by multiple testing because the probability of observing 3 or more significant results in 12 trials by chance alone is only 0.019 .

\section{Intraspecific crowding}

In crests, the sign of the slope of the emergenceversus-density trend line for 10 of 11 species was negative. The 2-tailed probability that a result as extreme or more extreme occurred by chance alone is 0.006 . In troughs, the sign of the slope of the trend line for 7 of

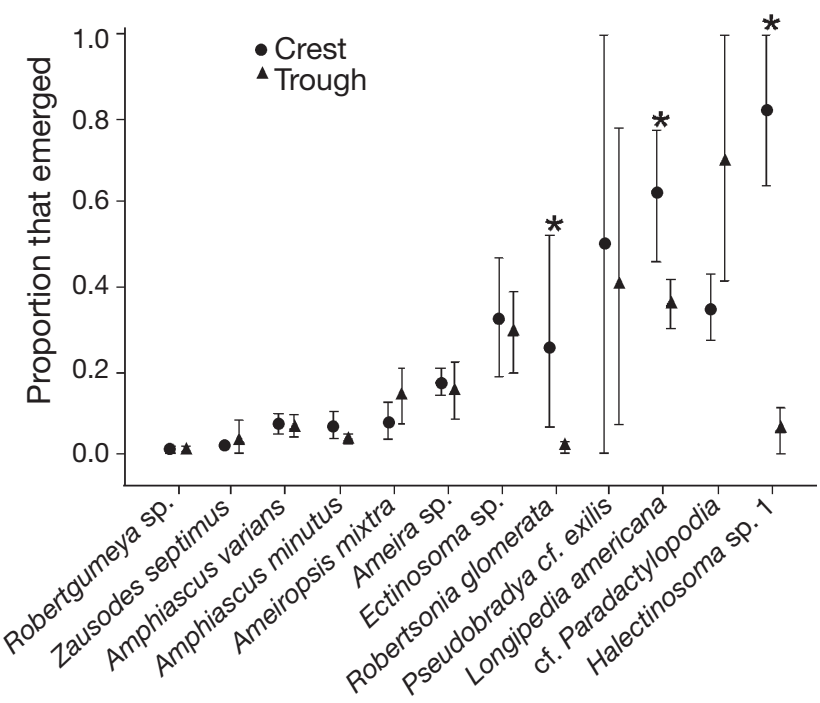

Fig. 2. Average proportions of a species' population that emerged from crests $(n=6)$ and troughs $(n=4)$ in 24 h, showing the substantial differences among species. Asterisks indicate instances where the proportions of a species that emerged from crests and troughs differed significantly. Lines extending from each symbol are $95 \%$ confidence intervals
9 species was negative. The 2-tailed probability that a result as extreme or more extreme occurred by chance alone is 0.09 .

\section{DISCUSSION}

\section{Do species differ in emergence?}

In the shelf species we studied, the proportions of the populations that emerged ranged, more or less continuously, from $\sim 1$ to $\sim 80 \%$ (Fig. 2). The same balance of costs and benefits seems unlikely to have caused $1 \%$ of the population of one species and $80 \%$ of another to emerge daily. Rather, the species seem to emerge for different reasons, so a general explanation of their emergence may be difficult to find. In this regard, they parallel wading-depth harpacticoids, where species can differ markedly in daily emergence (Walters \& Bell 1986).

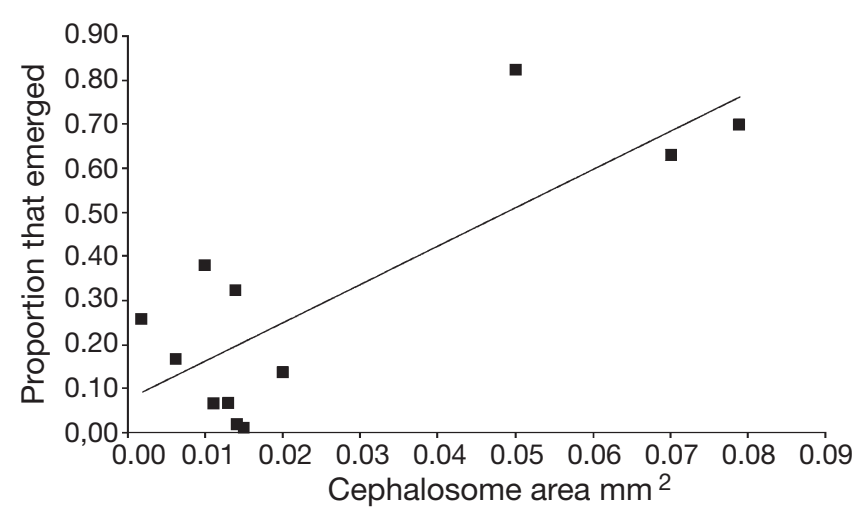

Fig. 3. Proportion of a species' population that emerged regressed on the average area of the adult female cephalosome in dorsal view, showing that the latter has considerable ability to predict the degree to which species emerge. Line is a least-squares fit

Table 3. For troughs, the difference in average $(\mathrm{n}=4)$ percentage emergence between pairs of species, showing which $(\mathrm{marked}$ with asterisks) differed significantly. Species are listed in order of increasing percentage emergence from troughs

\begin{tabular}{|c|c|c|c|c|c|c|c|c|c|}
\hline & $\begin{array}{c}\text { Robert- } \\
\text { gurneya } \\
\text { sp. }\end{array}$ & $\begin{array}{l}\text { Amphi- } \\
\text { ascus } \\
\text { minutus }\end{array}$ & $\begin{array}{c}\text { Amphi- } \\
\text { ascus } \\
\text { varians }\end{array}$ & $\begin{array}{l}\text { Ameir- } \\
\text { opsis } \\
\text { mixtra }\end{array}$ & $\begin{array}{c}\text { Ameira } \\
\text { sp. }\end{array}$ & $\begin{array}{c}\text { Ectino- } \\
\text { soma } \\
\text { sp. }\end{array}$ & $\begin{array}{c}\text { Longi- } \\
\text { pedia } \\
\text { americana }\end{array}$ & $\begin{array}{c}\text { Pseudo- } \\
\text { bradya } \\
\text { cf. exilis }\end{array}$ & $\begin{array}{c}\text { cf. } \\
\text { Paradac- } \\
\text { tylopodia }\end{array}$ \\
\hline Robertgurneya sp. & - & & & & & & & & \\
\hline Amphiascus minutus & $2.7^{*}$ & - & & & & & & & \\
\hline Amphiascus varians & $5.4^{*}$ & 2.6 & - & & & & & & \\
\hline Ameiropsis mixtra & $12.9^{*}$ & $10.2^{*}$ & 7.6 & - & & & & & \\
\hline Ameira sp. & $13.8^{*}$ & $11.0^{*}$ & 8.4 & 0.8 & - & & & & \\
\hline Ectinosoma sp. & $27.8^{*}$ & $25.2^{*}$ & $22.0^{*}$ & 14.8 & 14.0 & - & & & \\
\hline Longipedia americana & $34.9^{*}$ & $32.2^{*}$ & $29.6^{*}$ & $22.0^{*}$ & $21.2^{*}$ & 7.2 & - & & \\
\hline Pseudobradya cf. exilis & $37.8^{*}$ & $35.1^{*}$ & 32.4 & 24.9 & 24.0 & 10.0 & 2.8 & - & \\
\hline cf. Paradactylopodia & $69.0^{*}$ & $66.3^{*}$ & $63.7^{*}$ & $56.1^{*}$ & $55.2^{*}$ & $41.2^{*}$ & 34.1 & 31.2 & - \\
\hline
\end{tabular}


Table 4. For crests, the difference in average $(\mathrm{n}=6)$ percentage emergence between pairs of species, showing which (marked with asterisks) differed significantly. Species are listed in order of increasing percentage emergence from crests

\begin{tabular}{|c|c|c|c|c|c|c|c|c|c|c|c|}
\hline & $\begin{array}{c}\text { Robert- } \\
\text { gurneya } \\
\text { sp. }\end{array}$ & $\begin{array}{c}\text { Zauso- } \\
\text { des } \\
\text { septimus }\end{array}$ & $\begin{array}{l}\text { Amphi- } \\
\text { ascus } \\
\text { minutus }\end{array}$ & $\begin{array}{c}\text { Amphi- } \\
\text { ascus } \\
\text { varians }\end{array}$ & $\begin{array}{l}\text { Ameir- } \\
\text { opsis } \\
\text { mixtra }\end{array}$ & $\begin{array}{c}\text { Ameira } \\
\text { sp. }\end{array}$ & $\begin{array}{l}\text { Roberts- } \\
\text { onia } \\
\text { glomerata }\end{array}$ & $\begin{array}{c}\text { Ectino- } \\
\text { soma } \\
\text { sp. }\end{array}$ & $\begin{array}{c}\text { cf. Para- } \\
\text { dactylo- } \\
\text { podia }\end{array}$ & $\begin{array}{c}\text { Longi- } \\
\text { pedia } \\
\text { americana }\end{array}$ & $\begin{array}{l}\text { Halec- } \\
\text { tinosoma } \\
\text { sp. } 1\end{array}$ \\
\hline Robertgurneya sp. & - & & & & & & & & & & \\
\hline Zausodes septimus & 0.5 & - & & & & & & & & & \\
\hline Amphiascus minutus & $5.5^{*}$ & $5.0^{*}$ & - & & & & & & & & \\
\hline Amphiascus varians & $5.8^{*}$ & $5.2^{*}$ & 0.3 & - & & & & & & & \\
\hline Ameiropsis mixtra & $6.5^{*}$ & $6.0^{*}$ & 1.0 & 0.7 & - & & & & & & \\
\hline Ameira sp. & $15.8^{*}$ & $15.3^{*}$ & $10.3^{*}$ & $10.0^{*}$ & $9.3^{*}$ & - & & & & & \\
\hline Robertsonia glomerata & $24.4^{*}$ & $23.8^{*}$ & 18.9 & 18.6 & 17.9 & 8.6 & - & & & & \\
\hline Ectinosoma sp. & $31.2^{*}$ & $30.7^{*}$ & $25.7^{*}$ & $25.7^{*}$ & $24.7^{*}$ & 15.5 & 6.9 & - & & & \\
\hline cf. Paradactylopodia & $34.3^{*}$ & $33.8^{*}$ & $28.8^{*}$ & $28.8^{*}$ & $27.8^{*}$ & $18.5^{*}$ & 9.9 & 3.1 & - & & \\
\hline Longipedia americana & $61.5^{*}$ & $61.0^{*}$ & $56.0^{*}$ & $56.0^{*}$ & $55.0^{*}$ & $45.7^{*}$ & 37.1 & 30.2 & 27.2 & - & \\
\hline Halectinosoma sp. 1 & $81.2^{*}$ & $80.6^{*}$ & $75.7^{*}$ & $75.4^{*}$ & $74.7^{*}$ & $65.4^{*}$ & $56.8^{*}$ & $49.9^{*}$ & 46.9 & 19.7 & - \\
\hline
\end{tabular}

\section{Do Bell et al.'s characters predict the portion of a species' population that emerges?}

One of Bell et al.'s (1987) characters, the area of the adult female cephalosome in dorsal view (hereafter cephalosome area), significantly predicted the proportion of a species' population that emerged. In harpacticoids, the cephalosome and the mesosome (the 2 anterior body regions) carry the swimming legs and contain most of the muscles that move them. Therefore, swimming ability should be correlated with the combined volumes of the cephalosome and mesosome. Because of the way harpacticoids tend to be shaped (see Noodt 1971), the combined volumes of the cephalosome and mesosome tend to be correlated with the cephalosome area. (Harpacticoids are sexually dimorphic, but the general shapes of males and females are similar.) Therefore, the correlation of cephalosome area with the proportion of a species' population that emerged implies that differences in swimming ability explain at least a portion of the differences among species in the proportion that emerged (see also Palmer 1988). This inference is consistent with Thistle \& Sedlacek's (2004) finding that cephalosome area appears to be greater in species that emerge than in species that do not.

\section{Do species emerge in different proportions from different microhabitats?}

We found that 3 species differed significantly in the proportions of their populations that emerged from crests and troughs; that is, their emergence varied with microhabitat, as we hypothesized. This number may be an underestimate because the statistical power available to us was modest and because we sealed the base traps to the seabed, eliminating flow-driven effects.
That species can differ in their emergence from different microhabitats adds to the complexity of the emergence phenomenon. As is clear from our results and those on temporal differences (Walters \& Bell 1986, Service \& Bell 1987), the proportion of any given species' population that emerges depends on at least the month (Walters \& Bell 1986, Walters 1988, 1991), the time of day (Hauspie \& Polk 1973, Walters \& Bell 1986, Walters 1991), and the microhabitat.

\section{Intraspecific crowding}

Intraspecific crowding affected the emergence of some harpacticoid species from seagrass meadows (Service \& Bell 1987). We tested for this effect in our shelf species. For neither crests nor troughs did our analyses suggest that the proportion of a species' population that emerged increased, in general, as intraspecific crowding increased. Rather, for crests (troughs showed a similar trend), locations where a relatively small number of conspecifics occurred were those where the proportion of a species' population that emerged was relatively large. If species tend to be rare in areas that they perceive to be of poor quality, our results suggest that deterioration of the local environment prompts emergence.

\section{CONCLUSIONS}

(1) The portions of the species' populations that emerged daily ranged more or less continuously from $\sim 1$ to $\sim 80 \%$ for the emergent species we studied. A successful theory of emergence must be able to explain this variability.

(2) Although species' emergence behaviors are not constant, species in which a large proportion of the 
population emerges appear to be better swimmers than species with low emergence.

(3) Microhabitats can differ in the proportion of a species' population that emerges, presumably because environmental differences alter the cost-benefit ratio that underlies the behavior.

(4) On the basis of our regression analysis, emergence does not appear to increase with increased intraspecific crowding but may increase with deterioration of the local environment.

Acknowledgements. R. C. Tipper encouraged this study. J. Winne and D. Oliff built the traps. K. Suderman helped in the field. P. A. Jumars and C. Sedlacek gave advice. W. C. Burnett, N. H. Marcus, A. Sorgo, K. Suderman, M. Teasdale, A. B. Thistle, and $\mathrm{K}$. Vopel commented on versions of the manuscript. We thank these people for their kind help. The research was supported by ONR grant N00014-00-1-0007 to D.T. as an adjunct to SAX99.

\section{LITERATURE CITED}

Alldredge AL, King JM (1977) Distribution, abundance, and substrate preferences of demersal reef zooplankton at Lizard Island Lagoon, Great Barrier Reef. Mar Biol 41: $317-333$

Alldredge AL, King JM (1980) Effects of moonlight on the vertical migration patterns of demersal zooplankton. J Exp Mar Biol Ecol 44:133-157

Armonies W (1988) Active emergence of meiofauna from intertidal sediment. Mar Ecol Prog Ser 43:151-159

Bell SS, Walters K, Hall MO (1987) Habitat utilization by harpacticoid copepods: a morphometric approach. Mar Ecol Prog Ser 35:59-64

Bell SS, Hicks GRF, Walters K (1988) Active swimming in meiobenthic copepods of seagrass beds: geographic comparisons of abundances and reproductive characteristics. Mar Biol 98:351-358

Bruce PC (1991) Resampling stats. Resampling Stats, Arlington, VA

Buffan-Dubau E, Castel J (1996) Diel and seasonal vertical distribution of meiobenthic copepods in muddy sediments of a eutrophic lagoon (fish ponds of Arcachon Bay). Hydrobiologia 329:69-78

Commito JA, Tita G (2002) Differential dispersal rates in an intertidal meiofauna assemblage. J Exp Mar Biol Ecol 268: 237-256

Fleeger JW, Chandler GT, Fitzhugh GR, Phillips FE (1984) Effects of tidal currents on meiofauna densities in vegetated salt marsh sediments. Mar Ecol Prog Ser 19:49-53

Fuller CM, Butman CA (1988) A simple technique for finescale, vertical sectioning of fresh sediment cores. J Sediment Petrol 58:763-768

Grant J (1981) Sediment transport and disturbance on an intertidal sandflat: infaunal distribution and recolonization. Mar Ecol Prog Ser 6:249-255

Gray JS (1968) An experimental approach to the ecology of the harpacticoid Leptastacus constrictus Lang. J Exp Mar Biol Ecol 2:278-292

Hauspie R, Polk PH (1973) Swimming behaviour patterns in certain benthic harpacticoids (Copepoda). Crustaceana 25:95-103

Hicks GRF (1986) Distribution and behaviour of meiofaunal copepods inside and outside seagrass beds. Mar Ecol Prog Ser 31:159-170

Hicks GRF, Coull BC (1983) The ecology of marine meiobenthic harpacticoid copepods. Oceanogr Mar Biol Annu Rev 21:67-175

Huettel M, Gust G (1992) Impact of bioroughness on interfacial solute exchange in permeable sediments. Mar Ecol Prog Ser 89:253-267

Huettel M, Webster IT (2001) Pore water flow in permeable sediments. In: Boudreau BP, Jørgensen BB (eds) The benthic boundary layer. Oxford University Press, New York, p 144-179

Huettel M, Ziebis W, Forster S (1996) Flow-induced uptake of particulate matter in permeable sediments. Limnol Oceanogr 41:309-322

Huys R, Gee JM, Moore CG, Hamond R (1996) Marine and brackish water harpacticoid copepods, Part 1. Field Studies Council, Shrewsbury

Jacoby CA, Greenwood JG (1989) Emergent zooplankton in Moreton Bay, Queensland, Australia: seasonal, lunar, and diel patterns in emergence and distribution with respect to substrata. Mar Ecol Prog Ser 51:131-154

Marcus NH, Boero F (1998) Minireview: the importance of benthic-pelagic coupling and the forgotten role of life cycles in coastal aquatic systems. Limnol Oceanogr 43: $763-768$

Noodt W (1971) Ecology of the Copepoda. Smithson Contrib Zool 76:97-102

Palmer MA (1988) Dispersal of marine meiofauna: a review and conceptual model explaining passive transport and active emergence with implications for recruitment. Mar Ecol Prog Ser 48:81-91

Palmer MA, Allan JD, Butman CA (1996) Dispersal as a regional process affecting the local dynamics of marine and stream benthic invertebrates. Trends Ecol Evol 11: 322-326

Precht E, Huettel M (2003) Advective pore-water exchange driven by surface gravity waves and its ecological implications. Limnol Oceangr 48:1674-1684

Ravenel WS, Thistle D (1981) The effect of sediment characteristics on the distribution of two subtidal harpacticoid copepod species. J Exp Mar Biol Ecol 50:289-301

Reimers CE, Stecher HA, Taghon GL, Fuller CM, Huettel M, Rusch A, Ryckelynck N, Wild C (2004) In situ measurements of advective solute transport in permeable shelf sands. Cont Shelf Res 24:183-201

Remane A (1952) Die Besiedelung des Sandbodens im Meere und die Bedeutung der Lebensformtypen für die Ökologie. Zool Anz Suppl 16:327-359

Richardson MD, Briggs KB, Bibee LD, Jumars PA and 36 others (2001) Overview of SAX99: environmental considerations. IEEE J Ocean Eng 26:26-53

Robichaux DM, Cohen AC, Reaka ML, Allen D (1981) Experiments with zooplankton on coral reefs, or, will the real demersal plankton please come up? PSZN I: Mar Ecol 2: $77-94$

Service SK, Bell SS (1987) Density-influenced active dispersal of harpacticoid copepods. J Exp Mar Biol Ecol 114: $49-62$

Thistle D (2003) Harpacticoid copepod emergence at a shelf site in summer and winter: implications for hydrodynamic and mating hypotheses. Mar Ecol Prog Ser 248:177-185

Thistle D, Sedlacek L (2004) Emergent and non-emergent species of harpacticoid copepods can be recognized morphologically. Mar Ecol Prog Ser 266:195-200

Vopel K, Dehmlow J, Johansson M, Arlt G (1998) Effects of anoxia and sulphide on populations of Cletocamptus con- 
fluens (Copepoda, Harpacticoida). Mar Ecol Prog Ser 175: 121-128

Walters K (1988) Diel vertical migration of sediment-associated meiofauna in subtropical sand and seagrass habitats. J Exp Mar Biol Ecol 117:169-186

Walters K (1991) Influences of abundance, behavior, species composition, and ontogenetic stage on active emergence of meiobenthic copepods in subtropical habitats. Mar Biol 108:207-215

Walters K, Bell SS (1986) Diel patterns of active vertical migra-

Editorial responsibility: Kenneth L. Heck Jr. (Contributing Editor), Daulphin Island, Alabama, USA tion in seagrass meiofauna. Mar Ecol Prog Ser 34:95-103

Wieser W (1959) The effect of grain size on the distribution of small invertebrates inhabiting the beaches of Puget Sound. Limnol Oceanogr 4:181-194

Wells JBJ (1976) Keys to aid in the identification of marine harpacticoid copepods. Aberdeen University Press, Aberdeen

Ziebis W, Huettel M, Forster S (1996) Impact of biogenic sediment topography on oxygen fluxes in permeable seabeds. Mar Ecol Prog Ser 140:227-237

Submitted: March 28, 2003; Accepted: August 26, 2005

Proofs received from author(s): March 7, 2006 